\title{
The changing face after acute myocardial infarction
}

\author{
Hans Erik Bøtker ${ }^{1}$ (])
}

Received: 24 November 2019 / Accepted: 25 November 2019 / Published online: 12 December 2019

(c) Springer-Verlag GmbH Germany, part of Springer Nature 2019

Implementation of modern reperfusion therapy for STelevation myocardial infarction (STEMI) has improved immediate outcome vastly [16, 19]. The improvement has come along with intensified preventive medication against recurrent cardiac events [19] and the reduction in infarct size obtained by rapid and efficient reperfusion that ensures preservation of left ventricular function [18]. The improved survival following optimal reperfusion therapy has changed the epidemiology of MI. An increasing number of patients may survive with residual symptoms predominantly manifesting as heart failure and ultimately mortality in a longer perspective than experienced before the reperfusion era. The recognition that the improvement in long-term outcome has not reached the same level as short-term advancement [2] suggests that additional reduction of infarct size beyond the improvement achieved by reperfusion therapy is needed to improve long-term outcome [8].

Infarct size reduction beyond rapid reperfusion has been addressed by attempts to diminish the ischemia-reperfusion injury that inevitably occurs by opening the coronary artery during primary percutaneous coronary intervention. Cardioprotective interventions to encounter this goal include pharmacological as well as mechanical approaches. Experimental and clinical proof-of-concept studies have documented that cyclosporine A, postconditioning, and remote ischemic conditioning substantially attenuate ischemia-reperfusion injury $[2,12,14,17]$. However, translation of this diminution into a clinical benefit has been challenging [3, 6, 9]. Infarct size reduction has not consistently been reproduced in large clinical trials when biochemical biomarkers of myocardial injury are used for the assessment of infarct size rather than imaging modalities that allow quantification of infarct size and

This comment refers to the article available at https://doi. org/10.1007/s00395-019-0764-8.

\section{Hans Erik Bøtker}

heb@dadlnet.dk

1 Department of Cardiology, Aarhus University Hospital, Palle Juul-Jensens Boulevard 99, 8200 Aarhus N, Denmark myocardial salvage [3, 5, 7, 9]. Even if infarct size actually is reduced by the cardioprotective interventions, the reduction may not translate into a clinical benefit because infarct size with contemporary reperfusion therapy is small, i.e. in the order of magnitude of $15-17 \%$ of the left ventricle, by reperfusion alone [2]. Infarct sizes within this scale infrequently manifest with clinical symptoms within the usual 6-12 months follow-up period presented in most clinical trials [15].

Recent data indicate that infarct size remains an important determinant of outcome, i.e. cardiac mortality and postinfarction heart failure, following acute myocardial infarction even in the reperfusion era [18]. However, the highly favorable development in the outcome for STEMI patients and the disappointing results of cardioprotective treatments in terms of clinical efficacy raise the question whether infarct size reduction alone significantly improves clinical outcome, when other essential variables, including cardiovascular risk factors, comorbidities, post-procedural variables, and concurrent treatments, are taken into account [11].

In the current issue of Basic Research in Cardiology, Bochaton et al. [1] present the results of an observational post hoc analysis of their original CIRCUS trial that demonstrated absent additive effect of the cardioprotective agent, cyclosporine A, on clinical outcome beyond rapid revascularization [3]. In the current analysis, the authors used the neutral clinical outcome data from the original trial to study the relative weight of a variety of potential predictors compared to infarct size. The relative weight of infarct size on clinical outcome, defined as all-cause mortality and hospitalization for heart failure at 1 year, was only $18 \%$ while $82 \%$ was accounted for by the other specified variables. Although the specific numbers are certainly not universal values, the overall trend is of clinical importance for identifying focus areas to further improve long-term outcome in patients with a revascularized STEMI.

Although peak creatine kinase assessment for infarct size quantification may not be as accurate as imaging modalities, it is of importance to note that the analysis by Bochaton et al. confirms that infarct size remains a determinant for clinical 
outcome for STEMI patients even in the reperfusion era. Thus, infarct size reduction should be a continued focus area. Achievement of this goal probably requires a more multitargeted approach than anticipated until now [4].

The acknowledged limitations of the current post hoc study are the relatively low sample size and the inherent retrospective and non-prespecified character of the analysis. Residual confounding by unmeasured variables may have influenced the results with regard to the identification of the most important determinants of clinical outcome. As such, the study should be considered mainly exploratory. However, the recognition that additional variables beyond infarct size determine outcome following revascularization in STEMI is important because some of these variables are modifiable. The fact that neither age nor total ischemia time, which are well-known determinants of clinical outcome in STEMI patients undergoing rapid revascularization, did not come out as predictors in the present analysis may merely reflect the inherent limitations of the post hoc conditions using available data from a randomized trial. More importantly, however, the analysis identified predictors that may be modifiable by appropriate intervention, including postPCI TIMI flow grade, treatment with beta-blockers and angiotensin-converting enzyme inhibitors. Specifically, the study results suggest that microvascular obstruction [10] and beta-blocker treatment after acute myocardial infarction in revascularized patients without reduced left ventricular ejection fraction may be potential focus areas [13]. As the authors acknowledge, several targets may remain unidentified. Hence, the findings of the study stimulate a continued focus on reducing infarct size by a multitargeted approach and expanding the multitargeted approach to identify additional modifiable targets that can be addressed to further improve clinical outcome after revascularization of STEMI.

Acknowledgements This work was funded by the Novo Nordisk Foundation (DK) (Grant number NNF14OC0013337 and NNF15OC0016674), Strategiske Forskningsråd (Grant number 11-108354), and TrygFonden (Grant number 109624).

\section{References}

1. Bochaton T, Claeys MJ, Garcia-Dorado D, Mewton N, Bergerot C, Jossan C, Amaz C, Boussaha I, Thibault H, Ovize M (2019) Importance of infarct size versus other variables for clinical outcomes after PPCI in STEMI patients. Basic Res Cardiol. https:// doi.org/10.1007/s00395-019-0764-8

2. Botker HE, Kharbanda R, Schmidt MR, Bottcher M, Kaltoft AK, Terkelsen CJ, Munk K, Andersen NH, Hansen TM, Trautner S, Lassen JF, Christiansen EH, Krusell LR, Kristensen SD, Thuesen L, Nielsen SS, Rehling M, Sorensen HT, Redington AN, Nielsen TT (2010) Remote ischaemic conditioning before hospital admission, as a complement to angioplasty, and effect on myocardial salvage in patients with acute myocardial infarction: a randomised trial. Lancet 375:727-734. https://doi.org/10.1016/ S0140-6736(09)62001-8

3. Cung TT, Morel O, Cayla G, Rioufol G, Garcia-Dorado D, Angoulvant D, Bonnefoy-Cudraz E, Guerin P, Elbaz M, Delarche N, Coste P, Vanzetto G, Metge M, Aupetit JF, Jouve B, Motreff P, Tron C, Labeque JN, Steg PG, Cottin Y, Range G, Clerc J, Claeys MJ, Coussement P, Prunier F, Moulin F, Roth O, Belle L, Dubois P, Barragan P, Gilard M, Piot C, Colin P, De Poli F, Morice MC, Ider O, Dubois-Rande JL, Unterseeh T, Le Breton H, Beard T, Blanchard D, Grollier G, Malquarti V, Staat P, Sudre A, Elmer E, Hansson MJ, Bergerot C, Boussaha I, Jossan C, Derumeaux G, Mewton N, Ovize M (2015) Cyclosporine before PCI in patients with acute myocardial infarction. N Engl J Med 373:1021-1031. https://doi.org/10.1056/NEJMoa1505489

4. Davidson SM, Ferdinandy P, Andreadou I, Botker HE, Heusch G, Ibanez B, Ovize M, Schulz R, Yellon DM, Hausenloy DJ, Garcia-Dorado D, Action CC (2019) Multitarget strategies to reduce myocardial ischemia/reperfusion injury: JACC review topic of the week. J Am Coll Cardiol 73:89-99. https://doi.org/10.1016/j. jacc.2018.09.086

5. Eitel I, Stiermaier T, Rommel KP, Fuernau G, Sandri M, Mangner N, Linke A, Erbs S, Lurz P, Boudriot E, Mende M, Desch S, Schuler G, Thiele H (2015) Cardioprotection by combined intrahospital remote ischaemic perconditioning and postconditioning in ST-elevation myocardial infarction: the randomized LIPSIA CONDITIONING trial. Eur Heart J 36:3049-3057. https://doi. org/10.1093/eurheartj/ehv463

6. Engstrom T, Kelbaek H, Helqvist S, Hofsten DE, Klovgaard L, Clemmensen P, Holmvang L, Jorgensen E, Pedersen F, Saunamaki K, Ravkilde J, Tilsted HH, Villadsen A, Aaroe J, Jensen SE, Raungaard B, Botker HE, Terkelsen CJ, Maeng M, Kaltoft A, Krusell LR, Jensen LO, Veien KT, Kofoed KF, Torp-Pedersen C, Kyhl K, Nepper-Christensen L, Treiman M, Vejlstrup N, Ahtarovski K, Lonborg J, Kober L, Third Danish Study of Optimal Acute Treatment of Patients With STEMI-IPI (2017) Effect of ischemic postconditioning during primary percutaneous coronary intervention for patients with ST-segment elevation myocardial infarction: a randomized clinical trial. JAMA Cardiol 2:490-497. https://doi. org/10.1001/jamacardio.2017.0022

7. Gaspar A, Lourenco AP, Pereira MA, Azevedo P, Roncon-Albuquerque R Jr, Marques J, Leite-Moreira AF (2018) Randomized controlled trial of remote ischaemic conditioning in ST-elevation myocardial infarction as adjuvant to primary angioplasty (RICSTEMI). Basic Res Cardiol 113:14. https://doi.org/10.1007/s0039 5-018-0672-3

8. Hausenloy DJ, Botker HE, Engstrom T, Erlinge D, Heusch G, Ibanez B, Kloner RA, Ovize M, Yellon DM, Garcia-Dorado D (2017) Targeting reperfusion injury in patients with ST-segment elevation myocardial infarction: trials and tribulations. Eur Heart J 38:935-941. https://doi.org/10.1093/eurheartj/ehw145

9. Hausenloy DJ, Kharbanda RK, Moller UK, Ramlall M, Aaroe J, Butler R, Bulluck H, Clayton T, Dana A, Dodd M, Engstrom T, Evans R, Lassen JF, Christensen EF, Garcia-Ruiz JM, Gorog DA, Hjort J, Houghton RF, Ibanez B, Knight R, Lippert FK, Lonborg JT, Maeng M, Milasinovic D, More R, Nicholas JM, Jensen LO, Perkins A, Radovanovic N, Rakhit RD, Ravkilde J, Ryding AD, Schmidt MR, Riddervold IS, Sorensen HT, Stankovic G, Varma M, Webb I, Terkelsen CJ, Greenwood JP, Yellon DM, Botker HE, Investigators C-E-P (2019) Effect of remote ischaemic conditioning on clinical outcomes in patients with acute myocardial infarction (CONDI-2/ERIC-PPCI): a single-blind randomised controlled trial. Lancet 394:1415-1424. https://doi.org/10.1016/ S0140-6736(19)32039-2

10. Heusch G (2019) Coronary microvascular obstruction: the new frontier in cardioprotection. Basic Res Cardiol 114:45. https:// doi.org/10.1007/s00395-019-0756-8 
11. Kleinbongard P, Botker HE, Ovize M, Hausenloy DJ, Heusch $\mathrm{G}$ (2019) Co-morbidities and co-medications as confounders of cardioprotection-does it matter in the clinical setting? Br J Pharmacol. https://doi.org/10.1111/bph.14839

12. Lonborg J, Kelbaek H, Vejlstrup N, Jorgensen E, Helqvist S, Saunamaki K, Clemmensen P, Holmvang L, Treiman M, Jensen JS, Engstrom T (2010) Cardioprotective effects of ischemic postconditioning in patients treated with primary percutaneous coronary intervention, evaluated by magnetic resonance. Circ Cardiovasc Interv 3:34-41. https://doi.org/10.1161/CIRCINTERVENTIO NS.109.905521

13. Munkhaugen J, Ruddox V, Halvorsen S, Dammen T, Fagerland MW, Hernaes KH, Vethe NT, Prescott E, Jensen SE, Rodevand O, Jortveit J, Bendz B, Schirmer H, Kober L, Botker HE, Larsen AI, Vikenes K, Steigen T, Wiseth R, Pedersen T, Edvardsen T, Otterstad JE, Atar D (2019) BEtablocker treatment after acute myocardial infarction in revascularized patients without reduced left ventricular ejection fraction (BETAMI): rationale and design of a prospective, randomized, open, blinded end point study. Am Heart J 208:37-46. https://doi.org/10.1016/j.ahj.2018.10.005

14. Piot C, Croisille P, Staat P, Thibault H, Rioufol G, Mewton N, Elbelghiti R, Cung TT, Bonnefoy E, Angoulvant D, Macia C, Raczka F, Sportouch C, Gahide G, Finet G, Andre-Fouet X, Revel D, Kirkorian G, Monassier JP, Derumeaux G, Ovize M (2008) Effect of cyclosporine on reperfusion injury in acute myocardial infarction. N Engl J Med 359:473-481. https://doi.org/10.1056/ NEJMoa071142

15. Ross AM, Gibbons RJ, Stone GW, Kloner RA, Alexander RW, Investigators A-I (2005) A randomized, double-blinded, placebo-controlled multicenter trial of adenosine as an adjunct to reperfusion in the treatment of acute myocardial infarction (AMISTAD-II). J Am Coll Cardiol 45:1775-1780. https://doi. org/10.1016/j.jacc.2005.02.061

16. Schmidt M, Jacobsen JB, Lash TL, Botker HE, Sorensen HT (2012) 25 year trends in first time hospitalisation for acute myocardial infarction, subsequent short and long term mortality, and the prognostic impact of sex and comorbidity: a Danish nationwide cohort study. BMJ 344:e356. https://doi.org/10.1136/bmj. e356

17. Staat P, Rioufol G, Piot C, Cottin Y, Cung TT, L'Huillier I, Aupetit JF, Bonnefoy E, Finet G, Andre-Fouet X, Ovize M (2005) Postconditioning the human heart. Circulation 112:2143-2148. https ://doi.org/10.1161/CIRCULATIONAHA.105.558122

18. Stone GW, Selker HP, Thiele H, Patel MR, Udelson JE, Ohman EM, Maehara A, Eitel I, Granger CB, Jenkins PL, Nichols M, BenYehuda $O$ (2016) Relationship between infarct size and outcomes following primary PCI: Patient-level analysis from 10 randomized trials. J Am Coll Cardiol 67:1674-1683. https://doi.org/10.1016/j. jacc.2016.01.069

19. Szummer K, Wallentin L, Lindhagen L, Alfredsson J, Erlinge D, Held C, James S, Kellerth T, Lindahl B, Ravn-Fischer A, Rydberg E, Yndigegn T, Jernberg T (2017) Improved outcomes in patients with ST-elevation myocardial infarction during the last 20 years are related to implementation of evidence-based treatments: experiences from the SWEDEHEART registry 1995-2014. Eur Heart J 38:3056-3065. https://doi.org/10.1093/eurheartj/ehx515 